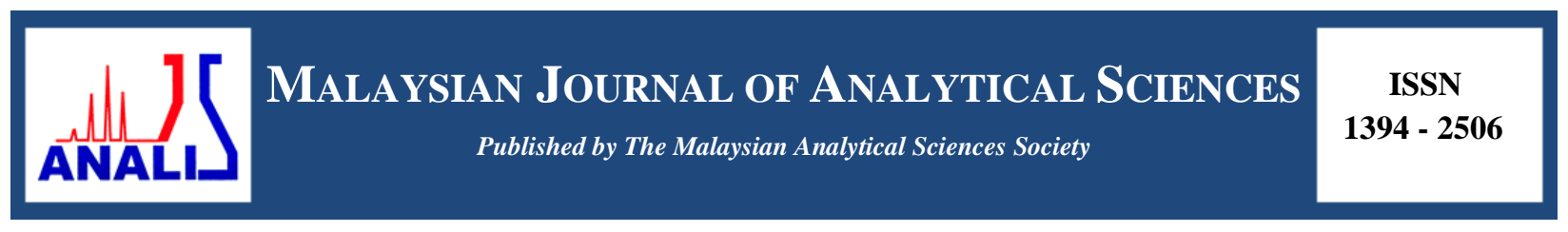

\title{
FABRICATION OF Y-TZP FOR DENTAL CROWNS APPLICATIONS BY COMBINING SLIP CASTING AND COLD ISOSTATIC PRESSING
}

\section{(Pembangunan Y-TZP untuk Aplikasi Korona Gigi melalui Penggabungan Kaedah Penuangan Buburan dan Penekanan Isostatik Sejuk)}

\author{
Chin Chuin Hao ${ }^{1}$, Andanastuti Muchtar ${ }^{1,2} *$, Che Husna Azhari ${ }^{1}$, Masfueh Razali ${ }^{3}$, Mohamed Aboras ${ }^{1}$ \\ ${ }^{1}$ Department of Mechanical and Materials Engineering, Faculty of Engineering and Built Environment \\ ${ }^{2}$ Fuel Cell Institute \\ Universiti Kebangsaan Malaysia, 43600 UKM Bangi, Selangor, Malaysia. \\ ${ }^{3}$ Periodontology Department, Faculty of Dentistry, \\ Universiti Kebangsaan Malaysia, Jalan Raja Muda Abdul Aziz, 50300 Kuala Lumpur, Malaysia.
}

*Corresponding author: muchtar@ukm.edu.my

Received: 5 February 2016; Accepted: 22 April 2016

\begin{abstract}
Yttria-stabilized tetragonal zirconia polycrystalline (Y-TZP) is a popular material for dental restoration because of its outstanding mechanical properties and biocompatibility. Cold isostatic pressing (CIP) and slip casting are among several consolidation methods for Y-TZP. These methods produce Y-TZP with high mechanical properties. This study aims to enhance the mechanical properties of Y-TZP by combining slip casting and CIP. Y-TZP samples were fabricated using CIP, slip casting, and their combination. Subsequently, the green bodies of the samples were sintered at $1600{ }^{\circ} \mathrm{C}$. Their mechanical properties (density and hardness) were tested and their microstructures were scrutinized under a scanning electron microscope. Compared with the other two methods, the combined method significantly improved the mechanical properties of Y-TZP. In addition, the combined method also produced a compact and homogeneous microstructure. Therefore, the combination of slip casting and CIP is recommended in the production of Y-TZP with high mechanical properties for dental crown applications.
\end{abstract}

Keywords: cold isostatic pressing, slip casting, colloidal processing

\begin{abstract}
Abstrak
Polikristal tetragon zirkonia yang distabilkan dengan yttria (Y-TZP) merupakan bahan restorasi pergigian yang popular disebabkan sifat mekanik dan bioserasi yang baik. Kaedah penekanan isostatik sejuk (CIP) dan penuangan buburan adalah kaedah pengukuhan yang lazim digunakan untuk Y-TZP. Kedua-dua kaedah ini berupaya menghasilkan Y-TZP yang bersifat mekanik tinggi. Kajian ini bertujuan meningkatkan sifat mekanik Y-TZP melalui gabungan penuangan buburan dan CIP. Sampel Y-TZP dihasilkan melalui kaedah penuangan buburan, CIP dan gabungan kedua-dua kaedah tersebut. Seterusnya, jasad anum yang terhasil disinter pada suhu $1600{ }^{\circ} \mathrm{C}$. Sifat mekanik sampel Y-TZP (ketumpatan dan kekerasan) diuji dan mikrostruktur juga diteliti di bawah mikroskop elektron imbasan. Kaedah gabungan didapati meningkatkan sifat mekanik Y-TZP dengan ketara. Selain itu, mikrostruktur yang padat dan homogen juga diperolehi. Justeru, gabungan kaedah penuangan buburan dan CIP dicadangkan untuk penghasilan Y-TZP yang bersifat mekanik tinggi dalam aplikasi korona gigi.
\end{abstract}

Kata kunci: penekanan isostatik sejuk, penuangan buburan, pemprosesan berkoloid 


\section{Chin et al: FABRICATION OF Y-TZP FOR DENTAL CROWNS APPLICATIONS BY COMBINING SLIP CASTING AND COLD ISOSTATIC PRESSING}

\section{Introduction}

Tetragonal zirconia polycrystalline partially stabilized by 3 mol\% of yttria (3Y-TZP) is well known for its superior mechanical properties among other dental ceramics [1,2]. Piconi et al. [3] remarked that Y-TZP has high flexural strength (> $900 \mathrm{MPa}$, four-point bending), high fracture toughness (approximately $10 \mathrm{MPa}^{\mathrm{m}}{ }^{1 / 2}$ ) and high hardness (12-14 GPa). The outstanding mechanical properties of Y-TZP are associated with the transformation toughening mechanism that involves phase transformation from tetragonal $(t)$ to monoclinic $(m)$ [4]. Given this mechanism, YTZP possesses adequate mechanical properties for clinical use as fixed prostheses when subjected to high stresses. Meanwhile, the excellent biocompatibility and optical properties of Y-TZP make it a suitable material for aesthetic and metal-free dental restoration [5, 6]. Recently, Y-TZP has been extensively applied in dental crown applications because it offers better aesthetics and biocompatibility compared with metal restoration $[4,5]$.

Most advanced ceramics, including Y-TZP, are processed through powder metallurgy methods, in which ceramic powders are compacted and undergo densification under elevated temperatures. Every procedure during ceramic processing (powder preparation, consolidation, and densification) can introduce detrimental heterogeneities, such as agglomerates and defects, which remain and exacerbate after sintering [7]. These heterogeneities may form large pores or flaws in the microstructure during densification and deteriorate the mechanical properties of the final products [8, 9]. Hence, minimizing the possibility of heterogeneity formation and achieving the desired spatial distribution phases (including pores) in green bodies is crucial [7].

There are many forming methods of ceramics such as micro-powder injection molding, pressing and sol-gel [1012]. Uniaxial pressing, cold isostatic pressing (CIP), and hot isostatic pressing (HIP) are among several consolidation processes that involve pressing in ceramic processing. Pressing is a dry-forming technique in ceramic processing that is known for producing critical parts in near net shape [13]. Compared with traditional methods such as uniaxial pressing, CIP can pressurize the powder compact from all directions. Thus, CIP produces green compacts with relatively high density and uniform packing using inexpensive tooling [14, 15].

Colloidal processing methods such as slip casting and tape casting have recently emerged as popular consolidation methods for ceramics. Colloidal processing methods have a great potential to offer high-quality green bodies with a high packing factor, thereby providing excellent mechanical properties for the final products [16-18]. Colloidal processing methods are highly recommended for submicron ceramic powder because submicron particles tend to agglomerate owing to their high specific surface area [17]. These agglomerates are invariably detrimental to the mechanical properties of ceramics. Colloidal processing controls the interparticle forces of ceramic particles through three mechanisms namely electrostatic, steric and electrosteric [7]. This method can effectively minimize the agglomeration of particles and thus improve the quality of green bodies. However, a suspension with excellent colloidal stability and rheological properties is required for a successful colloidal processing [19].

Slip casting and CIP are known for producing Y-TZP with excellent mechanical properties. This study aims to improve the mechanical properties of Y-TZP for dental crown applications by combining both slip casting and CIP.

\section{Materials}

\section{Materials and Methods}

Y-TZP nanopowder partially stabilized with 3 mol\% of $\mathrm{Y}_{2} \mathrm{O}_{3}$ (US Research Nanomaterials Inc., Houston, USA) was used in this study. This powder has a BET specific surface area of $30 \mathrm{~m}^{2} / \mathrm{g}$ and a true density of $5.89 \mathrm{~g} / \mathrm{cm}^{3} . \mathrm{The}$ transmission electron micrograph (TEM) of the as-received powder in Figure 1 shows that the primary particle size of the powder was approximately $20 \mathrm{~nm}$. Polyethyleneimine (PEI, Sigma-Aldrich) with an average molecular size of 50,000 was employed as a dispersant agent in colloidal processing. 


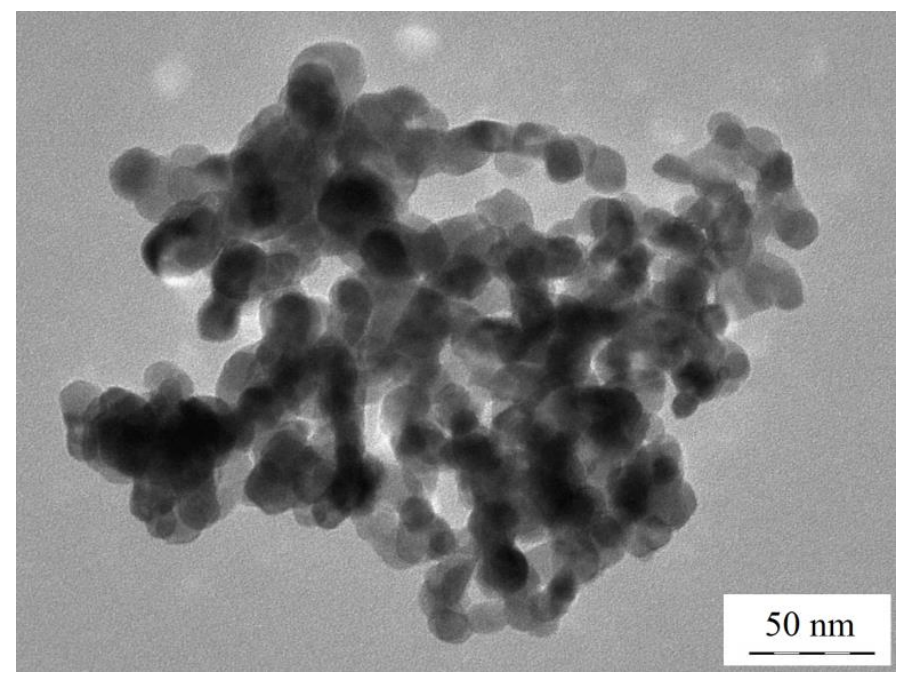

Figure 1. TEM image of the as-received Y-TZP powder

\section{Fabrication of Green Body}

A Y-TZP suspension with $30 \mathrm{wt} . \%$ powder loading was prepared. The dispersing medium was distilled water. The suspension was added with $0.4 \mathrm{wt} \%$ of $0.005 \mathrm{M}$ PEI, thoroughly mixed using a magnetic stirrer for $45 \mathrm{~min}$, and

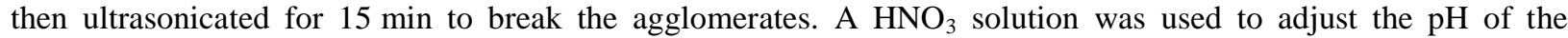
suspension to $\mathrm{pH}$ 2. The PEI amount and $\mathrm{pH}$ used in suspension preparation are optimized parameters from a previous study [20]. Slip casting was used to fabricate green bodies. The Y-TZP suspension was poured into a $15 \mathrm{~mm}$-diameter Teflon mold placed on top of a plaster of Paris block, which was then left for consolidation at room temperature. After $24 \mathrm{~h}$, the green bodies were carefully extracted from the mold.

For CIP, approximately $0.6 \mathrm{~g}$ of Y-TZP powder was measured and pressed into cylindrical disc shape through uniaxial pressing (Carver 4369, USA) in a $13 \mathrm{~mm}$-diameter mold (\#3619, Carver, USA). The powder was pressed at $25 \mathrm{MPa}$ and $10 \mathrm{~s}$ dwell time. Subsequently, the Y-TZP disc was subjected to CIP (Riken Seiki Co. Ltd., Japan) at $200 \mathrm{MPa}$ for $1 \mathrm{~min}$.

Combined method of slip casting and CIP was also used to fabricate green bodies. Y-TZP green bodies were first produced using slip casting method with the same procedures and parameters discussed previously. Then, the slipcasted green bodies were subjected to CIP at $200 \mathrm{MPa}$ for $1 \mathrm{~min}$.

\section{Sintering method}

The green bodies were sintered at $1600{ }^{\circ} \mathrm{C}$ by a two-step sintering method in a high-temperature furnace (VMK1800, Linn High Therm, Germany). The sintering profile is shown in Figure 2. The green bodies were initially heated to $600{ }^{\circ} \mathrm{C}$ at a rate of $3{ }^{\circ} \mathrm{C} / \mathrm{min}$ and maintained for $45 \mathrm{~min}$. Next, the green bodies were further heated to $1600{ }^{\circ} \mathrm{C}$, with a soaking time of 2 hours.

\section{Sample characterization}

The sintered densities of the Y-TZP samples were measured with a density meter (Newclassic MS, Mettler Toledo, Columbus, OH, USA) by applying Archimedes' immersion method. A field-emission scanning electron microscope, FESEM (Hitachi SU8000, Hitachi, Tokyo, Japan) was used to observe the microstructure of the Y-TZP samples. Before the examination, the sample surface was prepared by grinding using silicon carbide paper (600, 800 , and 1200 grit) and then polishing with diamond paste ( 3 and $1 \mu$ grit sizes). After surface preparation, thermal etching at $1200^{\circ} \mathrm{C}$ was conducted on the samples so that the grain boundaries can be observed clearly under the FESEM machine. During etching, the temperature increased to $1200{ }^{\circ} \mathrm{C}$ at a rate of $20^{\circ} \mathrm{C} / \mathrm{min}$ and maintained for $1 \mathrm{~h}$. Then, the temperature decreased to room temperature at the same rate. The Vickers hardness machine (EW422- 


\section{Chin et al: FABRICATION OF Y-TZP FOR DENTAL CROWNS APPLICATIONS BY COMBINING SLIP CASTING AND COLD ISOSTATIC PRESSING}

DAT, Eseway, Bowers Group, Camberly, UK) was used to examine the hardness of the Y-TZP samples. The Vickers hardness test was performed in accordance with ASTM C 1327-03 (Standard Test Method for Vickers Indentation Hardness of Advanced Ceramics). Six indentations were rendered on the prepared surface of the Y-TZP samples at $0.2 \mathrm{kgf}$ load and $10 \mathrm{~s}$ dwell time, and the average values were obtained. Similar procedures of surface preparation in the morphological test were also employed in this test. Finally, X-Ray diffraction (XRD, D8 Advance, Bruker, Billerica, MA, USA) was performed to observe the phase changes in Y-TZP after sintering.

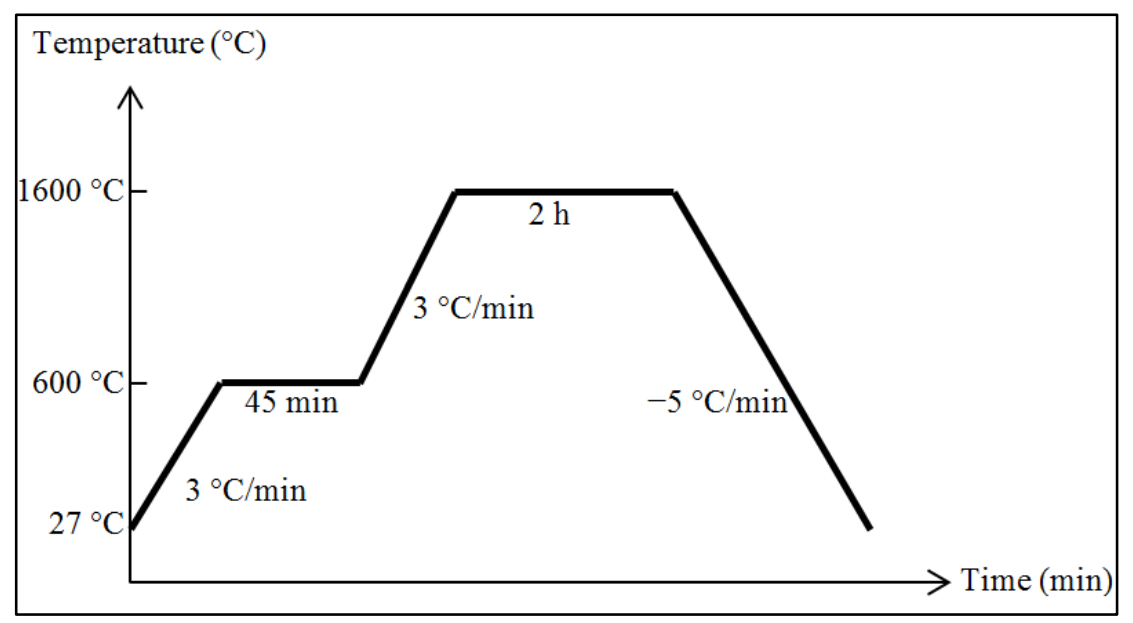

Figure 2. Sintering profile of Y-TZP samples

\section{Sintered density}

\section{Results and Discussion}

The sintered densities of the Y-TZP samples fabricated through different methods are shown in Figure 3. The sintered density of the Y-TZP sample fabricated through CIP was $98 \%$ of the theoretical density of Y-TZP $\left(6.1 \mathrm{~g} / \mathrm{cm}^{3}\right)$. Meanwhile, the sample processed with slip casting had the lowest sintered density, i.e., $92 \%$ of the theoretical density. The highest density of $99 \%$ was observed in the sample fabricated with the combination of slip casting and CIP.

Density is correlated with porosity, which is undesirable in ceramic processing because it deteriorates the mechanical strength of a ceramic body. The samples fabricated by CIP and the combined method achieved full densification (>98\%). The full densification of grains has been proven in many studies $[18,20]$ to yield high mechanical properties in Y-TZP. This result can be attributed to the high powder packing factor of the green bodies. The powder packing factor of a green body determines its quality. Inadequate packing of powder granules before sintering often results in irregularities such as pores and agglomerates after sintering which lead to low mechanical properties. Hence, high powder packing factor usually yields high sintered density. A consolidation process in ceramic processing must be carefully controlled to eradicate irregularities that deteriorate the mechanical properties of the final product. The density test results showed that the Y-TZP green bodies produced using CIP and the combined method had better powder packing than those produced using slip casting. This result indicates that the two methods are more suitable for consolidation than slip casting. Moreover, the CIP method significantly increased the density of slip-casted Y-TZP from $92 \%$ to $99 \%$. 


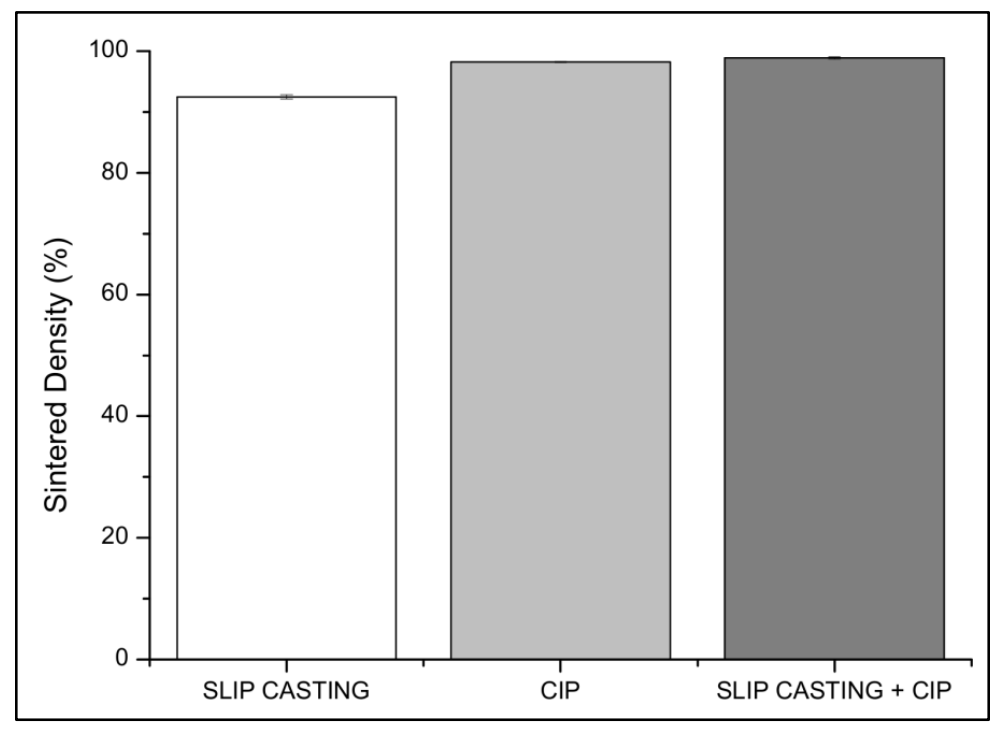

Figure 3. Relative sintered densities of Y-TZP samples

\section{Morphological analysis}

The scanning electron micrograph of the samples in Figure 4 shows that CIP produced a more compact and less porous microstructure compared with slip casting. This finding is corresponding to the density test results, in which the CIP sample showed a higher density than the slip casting sample. Average grain sizes of 614 and $569 \mathrm{~nm}$ were recorded in CIP and slip casting samples, respectively. However, the combined method produced a highly homogeneous and compact microstructure with an average grain size of $517 \mathrm{~nm}$. This compact and fine microstructure favors the production of Y-TZP samples with promising mechanical strength. Chin et al. [20] reported a smaller average grain size of $486 \mathrm{~nm}$ in the Y-TZP sample fabricated via slip casting method and a hardness of $10 \mathrm{GPa}$. In the present study, a higher hardness value was achieved with the combined method of slip casting and CIP (hardness test results will be discussed in following section) although the average grain size is larger compared to that of Chin et al. [20]. This is attributed to the compact microstructure with extremely low porosity yielded via the combined method in this study.

The microstructure of the CIP sample exhibited excessive grain growth primarily because uniaxial pressing and CIP cannot eliminate the agglomerates inherited from the raw Y-TZP powder. Ceramic powders in submicron size generally appear in the form of agglomerates, which are formed by bonded primary particles. Agglomeration always occurs because fine particles tend to reduce their surface energy [21]. These agglomerates, if left untreated, will persist until the end of processing and bring undesired sintered characteristics, such as high porosity, exaggerated grain growth, and flaws [22]. Coarse grains brought about by exaggerated grain growth in CIP samples (refer to Fig. 4b) are very detrimental to the mechanical properties because large grains are highly vulnerable to trans-granular cleavage, in which the crack propagates across the grain. Muchtar and Lim [23] also explained that trans-granular cleavage is not likely to occur in fine grains. Hence, a ceramic body with fine grain size is more resistant to transgranular fracture and possesses higher mechanical properties.

The combined method of slip casting and CIP yielded the most desired microstructure, which is compact and homogeneous because most agglomerates had been eliminated during colloidal processing. CIP further enhanced powder packing. Consequently, a nonporous homogeneous microstructure was obtained. 

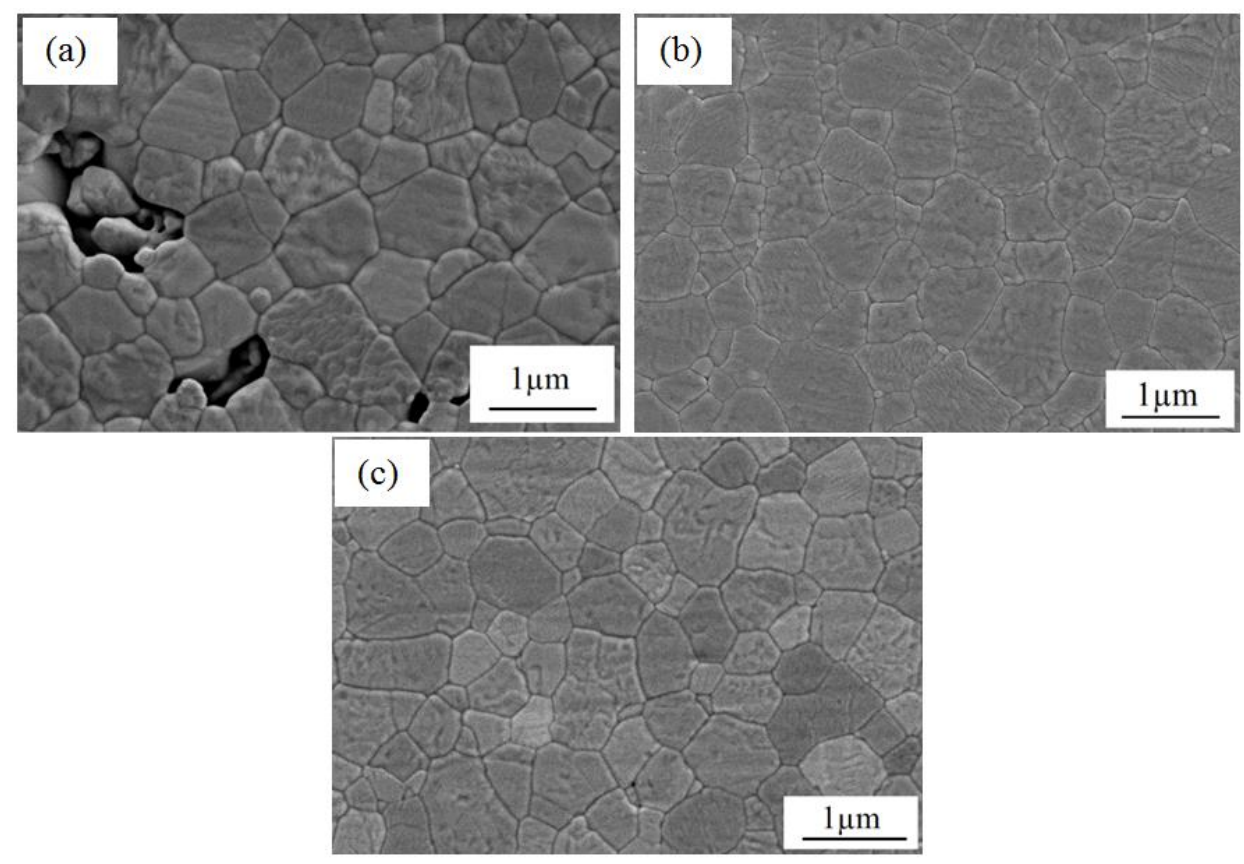

Figure 4. SEM images of Y-TZP samples fabricated through (a) slip casting, (b) CIP and (c) slip casting + CIP

\section{Hardness}

The materials of the crown should have high hardness values to prevent failure of the dental crown. The Vickers hardness of the samples fabricated with different methods is shown in Figure 5. The hardness of the CIP sample was slightly higher than that of the slip casting sample. However, CIP considerably improved the hardness of the slipcasted Y-TZP sample. Thus, the combined method yielded the highest hardness of $14.4 \mathrm{GPa}$. This is comparable to the highest hardness value of Y-TZP reported by Piconi et al. [3] which is $14 \mathrm{GPa}$. This result proves the effectiveness of CIP in improving the mechanical properties of slip-casted Y-TZP. The high hardness value of the sample fabricated by the combined method is ascribed to its compact and homogeneous microstructure. As stress concentrators that promote crack propagation, pores deteriorate the mechanical properties of the final products [18]. Thus, a compact microstructure can ensure favorable mechanical properties. A homogeneous and fine microstructure is also effective in impeding trans-granular fracture that usually results in low mechanical properties.

\section{X-Ray Diffraction (XRD)}

The XRD results in Figure 6 reveal a portion of monoclinic zirconia in the Y-TZP sample fabricated by CIP. This result can be attributed to the high stress level subjected to the Y-TZP powder during uniaxial pressing. $t-m$ phase transformation can be triggered by high stress level and exaggerated grain growth. Previous studies [24-26] reported that the grain size threshold for spontaneous $t-m$ transformation is approximately $1 \mu \mathrm{m}$. Coarse grains $>1 \mu \mathrm{m}$ in size were found in the microstructure of the CIP sample (Fig. 4b). Thus, this morphology encouraged the formation of monoclinic zirconia. The existence of the monoclinic phase is highly undesirable in dental crown applications because it poses the problem of low temperature degradation (LTD). LTD deteriorates the mechanical properties of Y-TZP at a fast rate in oral circumstance. Therefore, LTD limits the efficiency of Y-TZP in dental crown applications. Slip casting offers extra phase stability to the tetragonal phase because it produces the monophase of tetragonal zirconia. The combined method also offers good tetragonal phase stability because only a negligible amount of monoclinic zirconia was detected. 


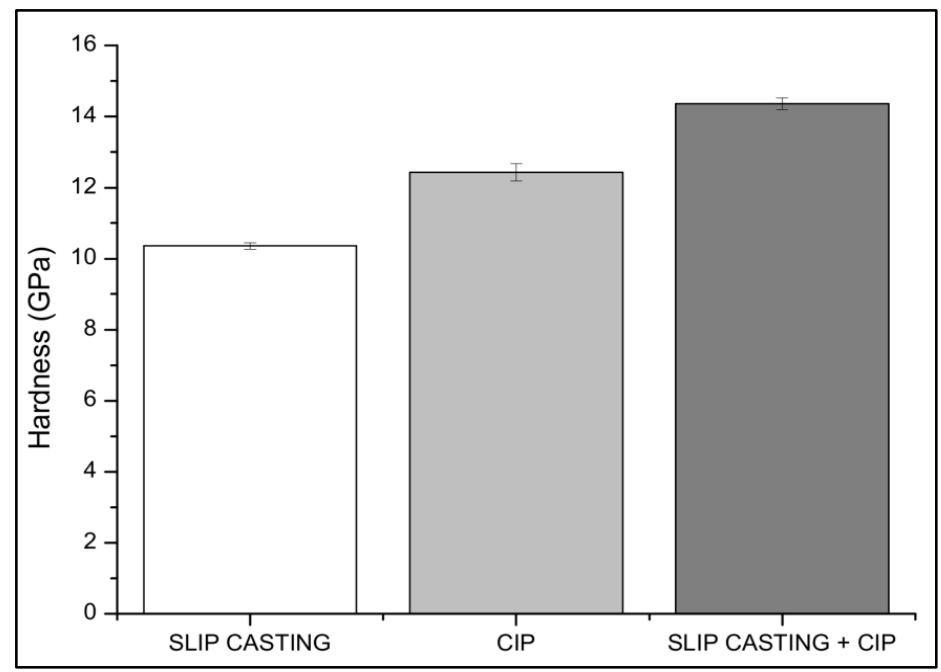

Figure 5. Hardness of Y-TZP samples

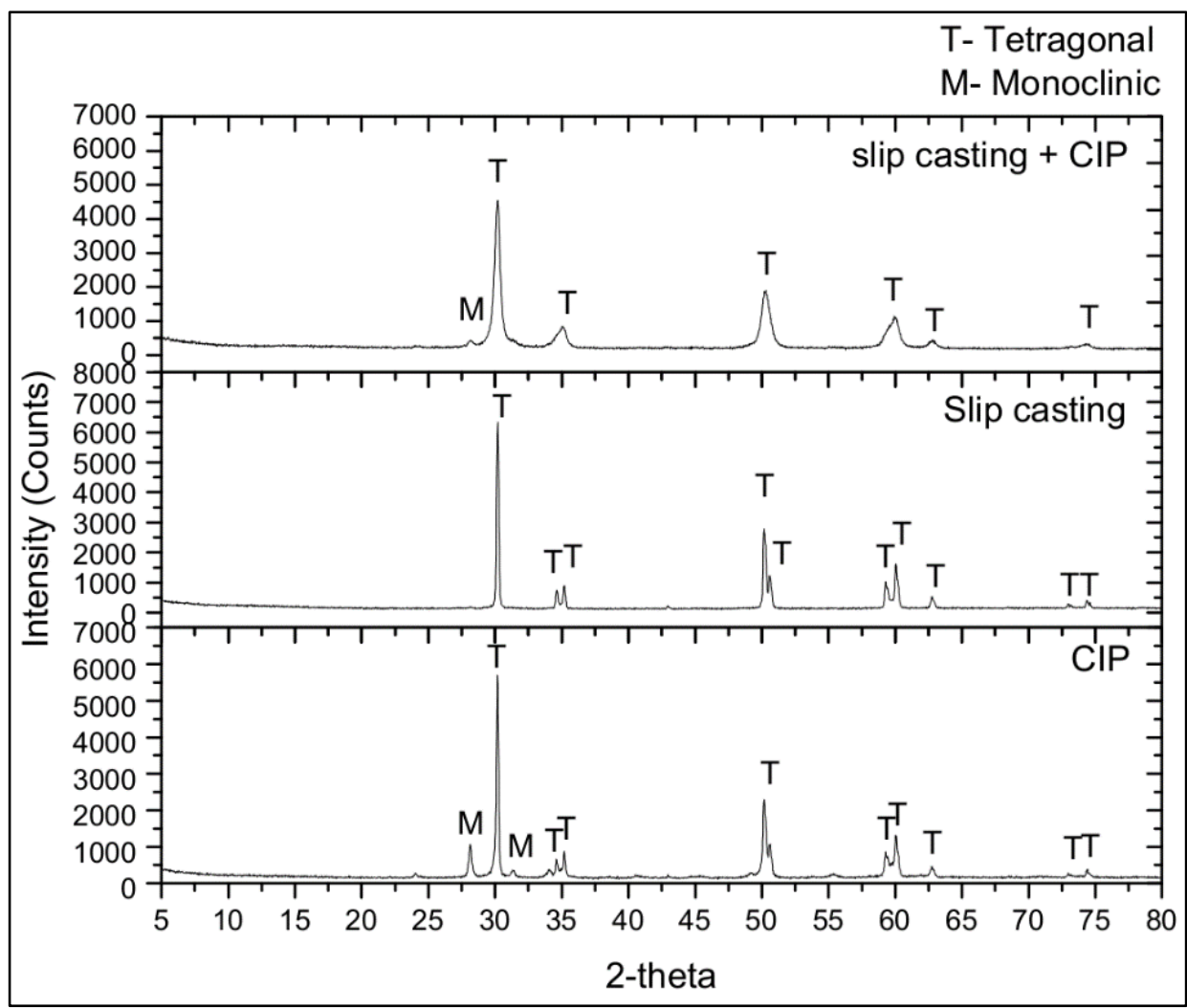

Figure 6. XRD results of Y-TZP samples processed with different methods 


\section{Chin et al: FABRICATION OF Y-TZP FOR DENTAL CROWNS APPLICATIONS BY COMBINING SLIP CASTING AND COLD ISOSTATIC PRESSING}

\section{Conclusion}

Both slip casting and CIP can produce Y-TZP with high mechanical properties. The CIP method offers better mechanical properties than the slip casting method. However, CIP method also encourages the formation of monoclinic zirconia, which can potentially jeopardize the mechanical properties of the final products. The combined method of slip casting and CIP is proven to be a better alternative processing route for Y-TZP. This method significantly enhances the mechanical properties of Y-TZP, for example, there was approximately $20 \%$ improvement in the hardness of Y-TZP fabricated via the combined method. This method also offers favorable tetragonal stability.

\section{Acknowledgement}

This work was supported by the Universiti Kebangsaan Malaysia (UKM) and the Ministry of Science, Technology and Innovation, Malaysia through the research sponsorship of DLP-2015-007 and FRGS/1/2013/SG06/UKM/01/1. The authors would like to acknowledge the support of the Centre for Research and Instrumentation Management (CRIM), UKM, and SIRIM for their excellent testing equipment.

\section{References}

1. Vleugels, J., Yuan, Z. X. and Van Der Biest, O. (2002). Mechanical properties of $\mathrm{Y}_{2} \mathrm{O}_{3} / \mathrm{Al}_{2} \mathrm{O}_{3}$-coated Y-TZP ceramics. Journal of the European Ceramic Society, 22 (6): 873 - 881.

2. Xu, T., Vleugels, J., Van Der Biest, O., Kan, Y. and Wang, P. (2006). Phase stability and mechanical properties of TZP with a low mixed $\mathrm{Nd}_{2} \mathrm{O}_{3} / \mathrm{Y}_{2} \mathrm{O}_{3}$ stabiliser content. Journal of the European Ceramic Society, 26 (7): $1205-1211$.

3. Piconi, C., Condo, S. G. and Kosmač, T. (2014). Chapter 11 - Alumina- and zirconia-based ceramics for loadbearing applications. Advanced Ceramics for Dentistry, 219 - 253.

4. Ozturk, O., Uludag, B., Usumez, A., Sahin, V. and Celik, G. (2008). The effect of ceramic thickness and number of firings on the color of two all-ceramic systems. The Journal of Prosthetic Dentistry, 100 (2): 99 106.

5. Manicone, P. F., Rossi, I. P. and Raffaelli, L. (2007). An overview of zirconia ceramics: basic properties and clinical applications. Journal of Dentistry, 35 (11): 819 - 826.

6. Persson, C., Unosson, E., Ajaxon, I., Engstrand, J., Engqvist, H. and Xia, W. (2012). Nano grain sized zirconia-silica glass ceramics for dental applications. Journal of the European Ceramic Society, 32 (16): 4105 4110.

7. Lewis, J. A. (2000). Colloidal processing of ceramics. Journal of the American Ceramic Society, 83 (10): 2341 $-2359$.

8. Briscoe, B. J., Khan, A. U. and Luckham, P. F. (1998). Stabilising zirconia aqueous suspensions using commercial polyvalent electrolyte solutions. Journal of the European Ceramic Society, 18 (14): 2169 - 2173.

9. Rafferty, A., Alsebaie, A. M., Olabi, A. G. and Prescott, T. (2009). Properties of zirconia-toughened-alumina prepared via powder processing and colloidal processing routes. Journal of Colloid and Interface Science, 329 (2): $310-315$.

10. Zakaria, H., Muhamad, N., Sulong, A. B., Ibrahim, M. H. I. and Foudzi, F. (2014). Moldability characteristics of $3 \mathrm{~mol} \%$ yttria stabilized zirconia feedstock for micro-powder injection molding process. Sains Malaysiana, 43 (1): $129-136$.

11. Osman, N., Ibarahim, N., Ishak, M. A. M. and Hassan, O. H. (2014). Characterization of cerate-zirconate ceramics powder prepared by three different methods: A comparative study. Sains Malaysiana, 43 (9): 1373 1378.

12. Ani, S. M., Muchtar, A., Muhamad, N. and Ghani, J. A. (2013). Characterisation of mixing uniformity and rheological properties of alumina-zirconia powder for ceramic injection moulding. Sains Malaysiana, 42 (9): $1311-1317$.

13. Ng, L. S., Loh, N. L. and Boey, F. Y. C. (1997). Cold-hot isostatic pressing of Mar M200 superalloy powders. Journal of Materials Processing Technology, 67 (1-3): 143 - 149.

14. Henderson, R. J., Chandler, H. W., Akisanya, A. R., Barber, H. and Moriarty, B. (2000). Finite element modelling of cold isostatic pressing. Journal of the European Ceramic Society, 20 (8): 1121 - 1128.

15. Mouzon, J., Glowacki, E. and Odén, M. (2008). Comparison between slip-casting and uniaxial pressing for the fabrication of translucent yttria ceramics. Journal of Materials Science, 43 (8): 2849 - 2856. 
16. Rafferty, A., Alsebaie, A. M., Olabi, A. G. and Prescott, T. (2009). Properties of zirconia-toughened-alumina prepared via powder processing and colloidal processing routes. Journal of Colloid and Interface Science, 329 (2): 310 - 315.

17. Rami, M.-L., Meireles, M., Cabane, B. and Guizard, C. (2009). Colloidal stability for concentrated zirconia aqueous suspensions. Journal of the American Ceramic Society, 92: 50 - 56.

18. Amat, N. F., Muchtar, A., Ghazali, M. J. and Yahaya, N. (2014). Suspension stability and sintering influence on yttria-stabilized zirconia fabricated by colloidal processing. Ceramics International, 40 (4): 5413 - 5419.

19. Liu, Y. and Gao, L. (2003). Deflocculation study of aqueous nanosized Y-TZP suspensions. Materials Chemistry and Physics, 78 (2): 480 - 485.

20. Chin, C. H., Muchtar, A., Azhari, C. H., Razali, M. and Aboras, M. (2015). Optimization of pH and dispersant amount of Y-TZP suspension for colloidal stability. Ceramics International, 41 (8): 9939 - 9946.

21. Balakrishna, P., Narasimha Murty, B. and Anuradha, M. (2009). A New process based agglomeration parameter to characterize ceramic powders. Journal of Nuclear Materials, 384 (2): 190 - 193.

22. Trunec, M. and Maca, K. (2014). Chapter 7 - Advanced ceramic processes. Advanced Ceramics for Dentistry, $123-150$.

23. Muchtar, A. and Lim, L. C. (1998). Indentation fracture toughness of high purity submicron alumina. Acta Materialia, 46 (5): 1683 - 1690.

24. Lange, F. F. (1982). Transformation toughening. Journal of Materials Science, 17 (1): 240 - 246.

25. Bravo-Leon, A., Morikawa, Y., Kawahara, M. and Mayo, M. J. (2002). Fracture toughness of nanocrystalline tetragonal zirconia with low yttria content. Acta Materialia, 50 (18): 4555 - 4562.

26. Zhang, Y. (2014). Making yttria-stabilized tetragonal zirconia translucent. Dental Materials, 30 (10): 1195 1203. 